\title{
Mathematical modelling of reaction-separation in an enzymatic membrane reactor during oligodextran production
}

\author{
Xianhui $\mathrm{Li}^{1}$, Ziran $\mathrm{Su}^{2}$, Xueming $\mathrm{Chen}^{3}$, Jianquan $\mathrm{Luo}^{4}$, and Manuel Pinelo ${ }^{3}$ \\ ${ }^{1}$ Guangdong University of Technology \\ ${ }^{2}$ Technical University of Denmark \\ ${ }^{3}$ Affiliation not available \\ ${ }^{4}$ Institute of Process Engineering Chinese Academy of Sciences
}

June 8, 2020

\begin{abstract}
Process analysis and optimization of an EMR system used for producing oligodextran are critical to improving EMR operating stability and cost effectiveness. We developed a mathematical model to evaluate the effects of operating conditions and membrane properties on the reaction-separation behavior of an EMR. Our analysis shows that tailoring a membrane with large porosity and uniform pore size distribution can simultaneously improve product quality and production efficiency. The optimum parameters of operating pressure and agitation speed depend on the selection of operating mode. A higher operating pressure was preferable for increasing the production efficiency of the EMR system under a water feeding mode. However, since the membrane suffered more severe fouling under a substrate feeding mode, extensive agitation was required to inhibit membrane fouling and enhance production yield. Our work paves the way for a new approach towards design of highly effective and low-consumptive EMR systems for oligodextran productio
\end{abstract}

\section{Hosted file}

image1.emf available at https://authorea.com/users/331266/articles/457956-mathematicalmodelling-of-reaction-separation-in-an-enzymatic-membrane-reactor-during-oligodextranproduction

\section{Introduction}

Oligodextran is a dextran derivative with a relatively low molecular weight $(\mathrm{Mw})(<70 \mathrm{kDa})$, which has been widely used as a prebiotic in food and as an antiphlogistic and antioxidant in pharmaceutical applications ${ }^{1,2}$. Production of oligodextran through enzymatic hydrolysis of industrial grade dextran is a safe and efficient process that minimizes secondary pollution (e.g. the generation of large amounts of organic wastewater in traditional acid hydrolysis) ${ }^{3,4}$. The combination of ultrafiltration (UF) with an enzymatic reactor, however, could purify the resulting oligodextran and narrow its $\mathrm{Mw}$ distribution which in turn would enhance oligodextran bioactivity ${ }^{5}$. Compared with the traditional enzymatic reactor and membrane separation hybrid process, which are performed separately, an enzymatic membrane reactor (EMR) that simultaneously performs enzymatic reaction and membrane separation enables enzyme reuse, reduces product inhibition, and avoids excessive hydrolysis of target products ${ }^{6}$. Several researchers have investigated the feasibility of EMR for oligodextran production ${ }^{7-10}$. For example, Torras et al. ${ }^{7}$ successfully fabricated a UF membrane loaded with dextranase for manufacturing oligodextrans. The Mw of oligodextran can be controlled by the loading amount of enzyme ${ }^{7}$ and the molecular weight cut-off (MWCO) of the membrane ${ }^{8}$. In our own previous study ${ }^{9,10}$ the membrane fouling that resulted from the enzyme was found to enable narrowing of membrane pore size distribution while oligodextran products of uniform $\mathrm{Mw}$ distribution were obtained. 
In spite of extensive experimental investigation of EMR performance, few efforts have been devoted to understanding the interaction between enzymatic reaction and membrane filtration, yet these are critical for the performance of the overall EMR process. Establishment of a reliable model, which describes the transport phenomena of oligodextran and enzymatic hydrolysis reactions, enables us to systematically investigate the influences of operating conditions and membrane properties on the performance of EMR and to optimize reactor design and membrane fabrication. However, most of previous studies dedicated to modelling EMR have focused on kinetic modeling and have considered only mass-transfer mechanisms ${ }^{11-13}$ in which the membrane only serves as a barrier or carrier of enzymes. In these studies the effect of membrane sieving on the transport mechanisms of the product has therefore not been taken into account. This is a critical knowledge gap that needs to be systematically addressed to guide the optimization of EMR for oligodextran production because the membrane also functions as a selective barrier in tailoring the molecular weight of the product. To the best of our knowledge no mathematical model regarding the EMR for oligodextran production has so far been reported.

The aim of the current study was therefore to develop a mathematical model to characterize the transport phenomena in EMR and predict EMR oligodextran production performance on the basis of the kinetics of dextran hydrolysis, the force balance model, and the stagnant film model as an approach for achieving process optimization. Our model evaluates membrane properties (pore size and porosity) and operating conditions (operating pressure and agitation speed) in relation to filtration performance. Furthermore, feeding modes (water feeding vs. substrate feeding) were also explored. Our work elaborates the inherent relationship between the operating parameters of EMR and its production efficiency, which can provide important insights into fundamental understanding and designing of EMR systems.

\section{Theoretical simulation}

The schematic diagram of a EMR for hydrolysis of dextran is shown inFigure 1. An initial fouling layer is rapidly formed at the start of the experiment and is assumed to be caused by the deposition of dextranase due to its strong hydrophobic interaction with the membrane ${ }^{9}$. Since the size of dextranase $(13 \mathrm{~nm})^{14}$ is larger than the membrane pore size $(10 \mathrm{~nm})^{10}$ used in this study, a cake layer would be formed on the membrane surface. After this stage, the dextran and enzyme would attach to each other for dextran degradation and then be deposited on the initial fouling layer. The hydrolyzed small dextran molecules would penetrate through the membrane. The entire filtration stage is therefore assumed to be dominated by the cake filtration mechanism. To facilitate model calculation, the following assumptions were used:

1. Complete mixing in bulk solution.

2. Uniform distribution of enzyme and dextran.

3. The activity of free enzyme is the same as that of the enzyme deposited on the membrane surface. In addition, the enzyme activity is independent of operating conditions.

Figure 1. Schematic diagram of an enzymatic membrane reactor for oligodextran production.

Kinetics of Dextran Degradation

A typical model to describe the changes in molecular weight $(\mathrm{Mw})$ during polymer degradation is shown in eq. (1) ${ }^{15}$. Thus, the reaction rate of the hydrolysis of dextran, i.e. the changes in the average $\mathrm{Mw}$ of the hydrolyzed dextran, can be described as

$M_{t}=\frac{M_{o}-M_{\lim }}{e^{k M_{\lim } t}}+M_{\lim }(1)$

where $M_{t}, M_{o}$, and $M_{l i m}$ represent the $\mathrm{Mw}$ at any reaction timet, the initial $\mathrm{Mw}$, and the limiting $\mathrm{Mw}$, respectively. $k$ is the rate constant which is calculated using experimental data. The final product of dextranase-catalyzed dextran degradation is isomaltose ${ }^{16}$, and thus the theoretical $M_{l i m}$ is $342 \mathrm{Da}$.

Permeate flux

The filtration equation can be expressed using cake filtration theory as follows ${ }^{17}$, 
$J=\frac{P}{\mu R_{t}}=\frac{P}{\mu\left(w_{c} \alpha_{\mathrm{av}}+R_{m}\right)}(2)$

where $J$ is the permeate flux, $\mu$ is viscosity, $P$ is the operating pressure, $R_{t}$ is the overall filtration resistance, and $R_{m}$ is the membrane intrinsic resistance calculated using the Kozeny-Carman equation ${ }^{18}$

$R_{m}=\frac{\left(1-\varepsilon_{m}\right)^{2} K_{p}}{\varepsilon_{m}^{3}}(3)$

where $\epsilon_{\mu}$ is the membrane porosity, and $K_{p}$ is membrane specific constant which was determined experimentally to be $8 \times 10^{12} \mathrm{~m}^{-1}$.

The average specific filtration resistance of the cake layer $\left(a_{a}\right)$ can be calculated by eq. (4)

$\alpha_{\mathrm{av}}=\frac{k_{o} S_{p}^{2}(1-\varepsilon)}{\rho_{S} \varepsilon^{3}}(4)$

where $k_{o}$ is the Kozeny constant, $\rho_{S}$ is the particle density, and $S_{p}$ is the specific surface area of particles. For spherical particles, the values of $k_{o}$ and $S_{p}$ are equal to 5.0 and $6 / d_{p}$, respectively, where $d_{p}$ is the particle diameter ${ }^{19}$. Since enzyme and dextran coexist in the cake layer, the flow channel of the liquid is made up of the porous spaces formed by both enzyme and dextran. Therefore $a_{a}$ was assumed as the connection of each resistance in parallel ${ }^{17}$, and can be expressed as

$\alpha_{\mathrm{av}}=\left[\frac{\omega}{\alpha_{e}}+\frac{1-\omega}{\alpha_{d}}\right]^{-1}(5)$

where $a_{\epsilon}$ and $a_{\delta}$ are the average specific filtration resistances of enzyme and dextran, respectively, and $\omega$ is the effective volume fraction of enzyme in the cake layer.

The cake mass, $w_{c}$, is obtained from

$w_{c}=\rho_{s}(1-\varepsilon) L(6)$

where $L$ is the cake thickness, and $\epsilon$ is the average cake porosity which can be calculated from following equation

$\varepsilon=1-\left(1-\varepsilon_{o}\right)\left(\frac{d_{p}+2 \delta}{d_{p}+D}\right)^{3}(7)$

where $\delta$ is the stern layer thickness, and $\epsilon_{o}$ is the porosity and is assumed to be $0.4^{20}$. The equilibrium distance between neighboring particles, $D$, can be evaluated based on the force balance at which the net interparticle force $\left(F_{n}\right)$ is equal to the solid compressive force $\left(F_{s}\right) \cdot F_{s}$ is generated from the fluid flowing through the cake, and can be calculated as

$F_{s}=-2 \pi \mu \frac{J\left(d_{p}+2 \delta\right)\left(3+2 r^{5}\right)}{2-3 r+3 r^{5}-2 r^{6}}(8)$

$r=\sqrt[3]{1-\varepsilon}(9)$

The $F_{n}$ can be estimated by using (DLVO) theory, and mainly consists of van der Waals force $\left(F_{v}\right)$ and electrostatic force $\left(F_{e}\right)$. The $F_{v}$ can be calculated as

$F_{v}=-\frac{d_{p} A_{H}}{24 D^{2}}\left(1-\frac{1}{1+\frac{\lambda_{p}}{\mathrm{cD}}}\right)$

where $\lambda_{\pi}$ is the characteristic wavelength of the particle and is assumed to be $100 \mathrm{~nm}, A_{H}$ is the Hamaker constant, and the constant $c$ is equal to $5.32^{20}$.

The $F_{e}$, calculated based on the Poisson-Boltzmann equation, is a function of an electric double layer thickness, and its reciprocal, $\kappa$, can be estimated by

$\kappa=\left[\frac{e^{2} \sum n_{i} z_{i}^{2}}{e_{0} e_{r} k_{B} T_{e}}\right]^{1 / 2}$

where $k_{B}$ is the Boltzmann constant, $e$ is the electrical charge $\left(=1.6 \times 10^{-19} \mathrm{C}\right), e_{o}$ is the absolute permittivity $\left(=8.85 \times 10^{-12} \mathrm{C}^{2} \mathrm{~J}^{-1} \mathrm{~m}^{-1}\right), e_{r}$ the dielectric constant, $z_{i}$ and $n_{i}$ are the valence of ions and the number of ions 
per unit volume in the bulk solution, respectively, and $T_{e}$ is the absolute temperature. As the thickness of an electric double layer is less than particle radius, the $F_{e}$ can be calculated as

$F_{e}=2 \pi e_{0} e_{r} \zeta^{2} \kappa\left[\frac{1}{1-\exp (-\kappa D)}-1\right](12)$

where $\zeta$ is the particle zeta potential.

$F_{e}$ can be also simplified as:

$F_{e}=\pi e_{0} e_{r} \frac{d_{p}^{2}}{\left(D+d_{p}\right)^{2}} \zeta^{2} \exp (-\kappa D)\left[1+\kappa\left(D+d_{p}\right)\right]$

The force balance model for determining particle deposition

The force balance model is used to determine the deposition possibility of particles (Fig. 1 ). The tangential drag force, $F_{t}$, induced by the tangential velocity in a stirred cell can be estimated by the modified Stokes law

$F_{t}=\frac{3}{4} \pi \mu d_{p}^{2} \gamma C_{1}$

where $C_{1}$ is a correction factor resulting from the membrane and the cake. The value of $C_{1}$ is equal to 1.7009 19. $\gamma$ is the shear rate at the membrane surface, $\gamma=\tau_{\varsigma} / \mu$. For a stirred cell, the shear stress $\left(\tau_{\varsigma}\right)$ can be calculated by ${ }^{21}$

where $\omega_{o}$ is the stirring angular velocity, and $R$ is the radius of the stirred cell, $\delta_{S}$ represents the thickness of momentum boundary layer, $\delta_{c}=\sqrt{\frac{\mu}{\rho \omega_{o}}}$, and $R_{c}$ is the critical radius and can be expressed as ${ }^{21}$

$R_{c}=\frac{D_{i}}{2} 1.23\left(0.57+0.35 \frac{D_{i}}{2 R}\right)\left(\frac{b}{2 R}\right)^{0.036} n_{b}^{0.116} \frac{\mathrm{Re}}{1000+1.43 \mathrm{Re}}(16)$

where $D_{i}$ is the diameter of the impeller, $h$ is the blade height, $R e$ is the Reynolds number and is defined as $\operatorname{Re}=\frac{\rho \omega_{o} D_{i}^{2}}{4 \mu}$, and $n_{b}$ is the number of blades. For the Millipore stirred cell (Amicon 8050) used in this study, $D_{i}=3.8 \mathrm{~cm}, R=2.1 \mathrm{~cm}, h=0.9 \mathrm{~cm}$, and $n_{b}=2$.

The normal drag force, $F_{p}$, induced by permeate flow can also be calculated by the modified Stokes law because of the very small Reynolds number:

$F_{p}=3 \pi \Theta \mu d_{p} C_{2}(17)$

The correction factor, $C_{2}$, in the equation can be obtained by

$C_{2}=0.36\left(R_{t} \operatorname{Ld}_{p}^{2} / 4\right)^{-2 / 5}$

Similarly, the modified Stokes law was used to calculate the inertial lift force $F_{l}$ as follows,

$F_{l}=3 \pi v_{l} \mu d_{p} C_{2}(19)$

where $v_{l}$ is the inertial lift velocity of particle and can be evaluated by the equation proposed by Vasseur and $\operatorname{Cox}{ }^{22}$

$v_{l}=\left(\frac{61 \gamma^{2}}{576 \nu}\right)\left(\frac{d_{p}}{2}\right)^{3}(20)$

where $\nu$ is the kinematic viscosity.

Finally, the net gravitational force, $F_{g}$, is obtained by

$F_{g}=\frac{\pi}{6} g\left(\rho_{s}-\rho\right) d_{p}^{3}(21)$

where $\rho$ and $\rho_{\mathrm{S}}$ are the densities of the fluid and particle, respectively. 
For a deposited particle, the external forces can be divided into normal and tangential directions as presented in Figure 1. If the net force $\left(F_{p}+F_{g}-F_{l}\right)$ is attractive (positive sign) in the normal directions and the friction force $\left(F_{f}\right)$ is larger than $F_{t}$ in the tangential directions, the particles are deposited on the membrane surface. If not, the particles will be swept back into the bulk solution. Thus the condition for the particles to stably stick on the membrane surface is given as

\{

$$
\begin{gathered}
F_{g}+F_{p}>F_{l} \\
F_{f}=\mu_{\max }\left(F_{g}+F_{p}-F_{l}\right)>F_{t}
\end{gathered}
$$

where $\mu_{\mu a \xi}$ is the maximum friction coefficient.

Solute flux

According to the study of Zydney et al. ${ }^{23}$, the solute flux $\left(N_{s}\right)$ across a porous membrane is defined by contributions from both convective and diffusive transport

$N_{s}=K_{c} J C_{w}-\varepsilon_{m} K_{d} D_{\infty} \frac{d C_{w}}{\mathrm{dz}}(23)$

where $K_{c}$ and $K_{d}$ are convective and diffusive hindrance factors, respectively, $C_{w}$ is the concentration of solute near the membrane surface, and $D_{[?]}$ is the diffusion coefficient of the solute. The diffusion coefficient of the dextran is calculated using the following correlation ${ }^{24}$

$D_{\infty}=7.667 \times 10^{-9} \times M_{w}^{-0.47752}$

where $M_{w}$ is the molecular weight in Da.

The observed sieving coefficient of solute $\left(S_{o}=C_{p} / C_{f}\right.$, where $C_{p}$ and $C_{f}$ are concentrations in the permeate and feed, respectively) can be calculated by using a stagnant film model with the actual membrane sieving coefficient $\left(S_{a}=C_{p} / C_{w}\right)^{25}$

$S_{o}=\frac{S_{a}}{\left(1-S_{a}\right) \exp \left(\frac{J}{k_{m}}\right)+S_{a}}(25)$

where $k_{m}$ is bulk mass transfer coefficient, and the value of $k_{m}$ in a stirred cell is calculated using the following correlation ${ }^{26}$

$k_{m}=0.23\left(\frac{\omega_{o} R^{2}}{\nu}\right)^{0.567}\left(\frac{\nu}{D_{\infty}}\right)^{0.33} \frac{D_{\infty}}{R}(26)$

For a membrane with one layer, that is no fouling layer, the $S_{a}$ can be obtained with eq. (27)

$S_{a}=\frac{S_{\infty} \exp \left(\mathrm{Pe}_{m}\right)}{S_{\infty}-1+\exp \left(\mathrm{Pe}_{m}\right)}(27)$

Once a fouling layer forms on the membrane surface, that is the membrane has two layers, the expression of $S_{a}$ is modified as 27

$S_{a}=\frac{S_{\infty f} \exp \left(\mathrm{Pe}_{\mathrm{mf}}\right) S_{\infty d} \exp \left(\mathrm{Pe}_{\mathrm{md}}\right)}{\left\{S_{\infty f}\left[S_{\infty d}+\exp \left(\mathrm{Pe}_{\mathrm{md}}\right)-1\right]+S_{\infty d} \exp \left(\mathrm{Pe}_{\mathrm{md}}\right)\left[\exp \left(\mathrm{Pe}_{\mathrm{mf}}\right)-1\right]\right\}}$

where the subscripts ' $f$ ' and ' $d$ ' denote the fouling and dense layers of the membrane, respectively. $P e_{m}$ and $S_{[?]}$ are the Peclet number and asymptotic sieving coefficient, respectively, and can be calculated as follows

$\mathrm{Pe}_{m}=\frac{\Theta \mathrm{K}_{c} \tau \delta_{m}}{K_{d} \varepsilon \Delta}(29)$

$S_{\infty}=\phi K_{c}(30)$

where $\tau$ is tortuosity, $\delta_{\mu}$ is the thickness of functional layer. For the fouling layer, the value of $\delta_{\mu}$ is equal to the cake thickness, $=(1-\lambda)^{2}$ is the equilibrium partition coefficient, $\lambda$ is the ratio of the solute radius $\left(R_{s}\right.$ ) to the pore radius $\left(R_{p}\right)$. For the irregular pore structures, e.g. the cake layer consists of different pore geometries, the $\lambda$ can be obtained as ${ }^{28}$

$\lambda=R_{s}\left(\frac{2 V_{p}}{S_{e}}\right)^{-1}$ 
where $V_{p}$ is the pore volume and $S_{e}$ is the pore surface area.

The radius of dextran is evaluated using the following experimental correlation ${ }^{24}$

$R_{S}=3.1 \times 10^{-11}\left(M_{w}\right)^{0.47752}$

$K_{c}$ and $K_{d}$ can be calculated using following expressions ${ }^{28}$

$K_{c}=\frac{3-(1-\lambda)^{2}}{2}\left(1-\frac{\lambda^{2}}{3}\right)(33)$

$K_{d}=1-1.004 \lambda+0.418 \lambda^{3}+0.21 \lambda^{4}-0.169 \lambda^{6}(34)$

Energy consumption

The energy consumption for a stirred dead-end filtration cell consists of the power dissipated by a stirrer $\left(P_{s}\right)$ and the power for generating the applied pressure $\left(P_{a}\right)$. Thus the specific energy consumption $(E)$ in $\mathrm{kWh}$ per a kilogram of product during the filtration process is presented by

$E=\frac{\int_{0}^{T}\left(P_{s}+P_{a}\right) \mathrm{dt}}{M_{p}}=\frac{\int_{0}^{T}\left(P_{s}+P_{a}\right) \mathrm{dt}}{Y M_{f}}(35)$

where $T$ is the filtration time, $M_{p}$ is the product mass in the permeate, $M_{f}$ is the substrate mass added in the filtration system, $Y$ is the yield.

$P_{a}=Q P(36)$

where $Q$ is permeate flow rate.

Power dissipated by a stirrer $\left(P_{s}\right)$ depends on the diameter of the impeller $\left(D_{i}\right)$, dimensionless power number $\left(N_{T}\right)$, the stirring angular velocity $\left(\omega_{o}\right)$, and the density of the fluid $(\rho)^{29} \cdot P_{s}$ can be calculated using eq. (37)

$P_{s}=N_{T} \rho \omega_{o}^{3} D_{i}^{5}(37)$

To generate high surface stress for alleviating membrane fouling, the minimum stirrer speed used in our system was $100 \mathrm{rpm}$, which gave a Reynolds number of 1130. As the Reynolds number is larger than 100, the $N_{T}$ of the Rushton impeller is independent of the Reynolds number and can be approximated to $5.0^{30}$.

Simulation algorithm

The equations were solved by the finite difference method using Matlabs software. The basic parameters used in the model calculation are summarized in Table $\mathbf{1}$. The simulation methodology, summarized schematically in Figure 2, was as follows:

1. The operating conditions $\left(P, \omega_{o}, C_{f}, T\right)$ and membrane properties $\left(R_{p}, \epsilon_{\mu}, \tau, S\right)$ were input in the Matlab program.

2. The initial permeate flux $J(0)$ at $t=0$ was calculated using eq. (2) without deposition of foulants.

3. The average $\mathrm{Mw}$ of dextran was determined based on the kinetics of dextran degradation using eq. (1).

4. The deposition possibility of particles was determined by the force balance model using eq. (22) to achieve the calculation of the total membrane filtration resistance $R_{t}$.

5. The permeate flux and solute flux at any time could be calculated step-by-step using the above procedures.

Figure 2. Schematic diagram of the methodology used in this work.

Table 1. Parameters used for model simulation

\section{Experimental materials and methods}

Materials 
Dextran substrate with $\mathrm{Mw}$ of $40 \mathrm{kDa}$ was obtained from Sinopharm Co Standard, China. The Bradford reagent and enzyme of dextranase (EC 3.2.1.11, dry powder from Penilisilium. Sp.) was obtained from SigmaAldrich Co. Ltd. The polyether sulfone UF membrane with MWCO of $20 \mathrm{kDa}$ (PES20) was purchased from AMFOR INC, USA. Milli-Q water was used for dissolving enzyme and substrate in the experiment.

Experimental procedures

An enzymatic hydrolysis experiment using EMR for producing oligodextran was conducted to validate the established model. The detailed experimental procedures have been described in our previous study ${ }^{10}$ and a brief description is provided here. A piece of PES20 membrane was placed in a $50 \mathrm{ml}$ dead-end stirred cell (Amicon 8050, Millipore, U.S.A) with an effective membrane surface area of $14 \mathrm{~cm}^{2}$. A constant pressure mode was achieved by filling the cell with nitrogen gas. A mixture of $0.05 \mathrm{~g} / \mathrm{L}$ dextranase and $50 \mathrm{~g} / \mathrm{L}$ dextran substrate was added to the cell. DI water was continuously added to the cell to maintain the feed volume constant of $50 \mathrm{ml}$ for an operation duration of $120 \mathrm{~min}$ at different agitation speeds and operating pressure. The permeate flux was measured every $30 \mathrm{~min}$. The permeate samples were heated in boiling water for 1 min and then stored at $4{ }^{\circ} \mathrm{C}$ for further analysis.

The total dextran concentration in the permeate was measured using the phenol-sulfuric acid method. All samples were diluted 500 times with DI water. Next, a mixture of $2 \mathrm{ml}$ diluted sample, $5 \mathrm{ml}$ of sulfuric acid, and $1 \mathrm{ml}$ of $6 \%(\mathrm{v} / \mathrm{v})$ phenol was added to a glass tube. The mixture was shaken for $1 \mathrm{~min}$ and then allowed to stand for $30 \mathrm{~min}$. The sample was tested at an absorbance of $490 \mathrm{~nm}$ in a UV-2100 Spectrophotometer to determine the dextran concentration. Glucose solutions with concentrations in the range of $0.01 \mathrm{~g} / \mathrm{L}-0.07$ $\mathrm{g} / \mathrm{L}$ were used for calibration.

\section{Results and Discussion}

Kinetics analysis and model validation

The kinetic analysis of the changes in $\mathrm{Mw}$ of the hydrolyzed dextran was modelled using eq. (1). The rate constant, $k$, is related to the concentrations of substrate and enzyme ${ }^{34}$, which could be obtained by fitting with experimental data as presented inTable $\mathbf{S 1}$. The simulated results in reasonable agreement with the experimental data (Figure 3a ). The obtained value of $k$ decreased with increasing concentration of dextran substrate (Figure 3b ). The curve-fitting results show that the values of $k$ follow an exponential relationship with dextran concentration $\left(c_{d}\right)$, with a correlation coefficient $\mathrm{R}^{2}>0.99$ as shown in Figure $\mathbf{3} \mathbf{b}$, and its values can be expressed with following equation:

$k=0.0001 e^{-0.017 c_{d}}(38)$

The Mw of dextran can be predicted when the dextranase concentration is fixed as $0.05 \mathrm{~g} / \mathrm{L}$ by combing eqs. (1) and (38).

To validate the developed model, the simulated permeate flux and the oligodextran concentration in the permeate were compared with the experimental data at different operating pressures as presented inFigure 4, where the simulated permeate flux can be seen to agree well with the experimental data. Increasing operating pressure enhanced the permeate flux as a result of higher driving force. It is noteworthy that the permeate flux decreased significantly in the initial stage but also gradually increased with prolonged operation time. This was a result of the dextran being hydrolyzed into small molecules which could penetrate through the membrane into the permeate and thus alleviate concentration polarization. Similarly, the simulated permeate concentration was in relatively good agreement with the experimental results (Figure $\mathbf{4 b}$ ). The relatively large discrepancy in the initial 30 min may have resulted from non-uniform distribution of membrane pore size and the wider molecule weight distribution of dextran substrate ${ }^{35}$, which allowed some smaller dextran molecules to penetrate through the large membrane pores into the permeate in the initial filtration stage. The permeate concentration increased as the operation proceeded due to generation of a large amount of smaller oligodextran molecules following sufficient hydrolysis. However, increasing operating pressure reduced the permeate concentration because the denser fouling layer, the shorter the retention time for dextran hydrolysis, and with enhanced water convection transport at higher pressure, oligodextran rejection improved and its 
concentration in the permeate fell ${ }^{36}$. These observations therefore indicate that the developed model is an efficient tool for simulating the filtration characteristics of an EMR.

Figure 3 . Effect of dextran concentration on (a) the variation of average Mw with reaction time and (b) the values of rate constant $(k)$ in a batch system with free enzyme. The simulated results are plotted as curves, while the experimental results are presented as discrete symbols.

Figure 4. Experimental (solid line) and simulated (discrete symbols) profiles of (a) permeate flux and (b) permeate concentration versus operation time with membrane pore size of $10 \mathrm{~nm}$ and membrane porosity of 0.8. Substrate concentration: $50 \mathrm{~g} / \mathrm{L}$, enzyme concentration: $0.05 \mathrm{~g} / \mathrm{L}$, agitation speed: $160 \mathrm{rpm}$, and feeding mode: water feeding.

Predicting influence of membrane properties on filtration performance

This section evaluates the role of membrane properties (i.e., membrane pore size and porosity) in determining the filtration performance of an EMR. As discussed in the section on theoretical simulation, the membrane pore size determines the convective and diffusive hindrance factors (i.e., $K_{c}$ in eq. (33) and $K_{d}$ in eq. (34)) and thus affects the sieving efficiency of solutes. Figure $\mathbf{5}$ shows the permeate flux and permeate concentration of an EMR as a function of membrane pore size. It is evident that the tighter membrane (smaller pore size) suffers from more severe concentration polarization leading to lower permeate flux $^{37}$ (Figure 5a ). The flux difference becomes smaller in the later stage, which is attributed to the reduction of degree of concentration polarization as more products passed through the membrane. Since the tighter membrane rejects more dextran, it has a low permeate concentration compared to the membrane with larger pore size at the same operation time in the initial stage (Figure 5b ). Although the membrane with large pore size has a higher filtration efficiency, the membrane with small pore size benefits from prolonged retention time which enables sufficient hydrolysis of substrate and in turn produces more uniform and smaller oligodextran molecules ${ }^{10}$. However, further increase in operation time leads to decrease of permeate concentration (Figure 5b ) because substrate concentration decreases with increase of the operation time under the water feeding mode.

The membrane porosity is also of particular significance because, on one hand, it affects the relationship between the convection and diffusion transportation of solutes (i.e, $P e_{m}$ in eq. (29)) and, on the other hand, it determines the membrane intrinsic resistance (i.e, $R_{m}$ in eq. (3)) and retention time that relate to separation efficiency. Figure 6 presents the variations of permeate flux and permeate concentration at different membrane porosities. The membranes with different porosities present a similar filtration performance in the initial filtration process. However, as more oligodextran products are collected in the permeate, the concentration polarization decreases and the role of membrane resistance in the total filtration resistance is enhanced. A higher membrane porosity causes a decrease of the membrane resistance (i.e. smaller $R_{m}$ in eq. (3)). As a result, the membrane with higher porosity has larger permeate flux in the later filtration process, which leads to decrease of the permeate concentration (Figure 6 ). This result is explained by the increase in oligodextran rejection due to the dilution effect at higher flux ${ }^{38}$. The developed model elaborates the inherent relationship between membrane properties and reaction-separation efficiency and shows that selection of a membrane with large porosity and uniform pore size distribution in an EMR is beneficial for the improvement of filtration efficiency and quality of products.

Figure 5. Simulation investigation of the effect of the pore size of membrane on (a) permeate flux and (b) permeate concentration with membrane porosity of 0.8 . Substrate concentration: $50 \mathrm{~g} / \mathrm{L}$, enzyme concentration: $0.05 \mathrm{~g} / \mathrm{L}$, operating pressure: 3 bar, agitation speed: $1000 \mathrm{rpm}$, and feeding mode: water feeding.

Figure 6. Simulation investigation of the effect of membrane porosity on (a) permeate flux and (b) permeate concentration with membrane pore size of $10 \mathrm{~nm}$. Substrate concentration: $50 \mathrm{~g} / \mathrm{L}$, enzyme concentration: $0.05 \mathrm{~g} / \mathrm{L}$, operating pressure: $3 \mathrm{bar}$, agitation speed: $1000 \mathrm{rpm}$, and feeding mode: water feeding.

Predicting influence of operating conditions on filtration performance

We systematically investigated the influence of agitation speed, operating pressure and feeding mode on the 
filtration performance of an EMR. As expected, the permeate flux increases at high agitation speed (Figure 7a ). This positive phenomenon is attributed to a thinner concentration polarization layer at higher agitation (a strong shear force on the membrane surface) ${ }^{36}$. There were no changes of the permeate flux when agitation speed is less than $1000 \mathrm{rpm}$ because the shear force generated by lower agitation is not enough to mitigate concentration polarization (Figure S1 ). The increased concentration polarization caused higher solute flux (Figure 7b ). A similar trend is observed with the permeate flux with increasing operating pressure, which is attributed to a greater driving force at higher operating pressure (Figure 8a ). The intensified driving force could accelerate the penetration of oligodextran products through the membrane and thus result in higher solute flux (Figure 8b ). However, increasing the agitation speed and operating pressure decreases the permeate concentration due to a dilution effect at higher permeate flux under the water feeding mode (Figure $7 \mathrm{c}$ and $\mathbf{8 c}$ ).

The substrate feeding mode is an alternative for enhancing the concentration of oligodextran in the permeate. Unlike the water feeding mode where pure water is continuously fed into the system, in the substrate feeding mode the dextran at constant concentration is continuously fed into the reaction system to maintain a constant feed volume. The simulations on the influence of feeding mode are summarized in Figure $\mathbf{9}$. It is no doubt that the membrane suffers from more severe fouling under the substrate feeding mode ${ }^{10}$, which thus leads to an obvious decrease of permeate flux (Figure 9a ). The decreased permeate flux under the substrate feeding mode reduced the oligodextran passing through the membrane, as is evidenced by the lower solute flux (Figure 9b ). The solute flux increases monotonically with prolonged operation duration under the substrate feeding mode, while the solute flux gradually decreases in the later stages under the water feeding mode owing to reduced substrate concentration in the EMR (Figure 9b ). This phenomenon is more prominent in the variation of permeate concentration with operation time (Figure 9c ). The increased permeate concentration is beneficial in terms of decrease in energy consumption (based on eq. (35)). This analysis was confirmed by the finding that the substrate feeding mode exhibits a lower specific energy consumption $(2.4 \mathrm{kWh} / \mathrm{kg})$ compared to the water feeding mode $(3.5 \mathrm{kWh} / \mathrm{kg})$ (Figure 9d ). However, the oligodextran yield obtained under the substrate feeding mode $(28.2 \%)$ is obviously lower than that obtained under the water feeding mode $(89.6 \%$ ) (Figure 9d ), which is attributed to the higher substrate concentration in the feed of the former mode so that the enzyme is not enough to achieve a high conversation rate ${ }^{39}$. The lower permeate flux under the substrate feeding mode causes a smaller permeate volume, and even with a higher permeate concentration, the mass of product is still smaller. Therefore optimization of system operating conditions is of great significance for the stable and efficient operation of an EMR system.

Figure 7. Simulation investigation of the effect of agitation speed on (a) permeate flux, (b) solute flux, and (c) permeate concentration with membrane pore size of $10 \mathrm{~nm}$ and membrane porosity of 0.8 . Substrate concentration: $50 \mathrm{~g} / \mathrm{L}$, enzyme concentration: $0.05 \mathrm{~g} / \mathrm{L}$, operating pressure: 1 bar, and feeding mode: water feeding.

Figure 8. Simulation investigation of the effect of operating pressure on (a) permeate flux, (b) solute flux, and (c) permeate concentration with membrane pore size of $10 \mathrm{~nm}$ and membrane porosity of 0.8 . Substrate concentration: $50 \mathrm{~g} / \mathrm{L}$, enzyme concentration: $0.05 \mathrm{~g} / \mathrm{L}$, agitation speed: $1000 \mathrm{rpm}$, and feeding mode: water feeding.

Figure 9. Simulation investigation of the effect of feeding mode on (a) permeate flux, (b) solute flux, (c) permeate concentration, and (d) yield and specific energy consumption with membrane pore size of $10 \mathrm{~nm}$ and membrane porosity of 0.8. Substrate concentration: $50 \mathrm{~g} / \mathrm{L}$, enzyme concentration: $0.05 \mathrm{~g} / \mathrm{L}$, agitation speed: $1000 \mathrm{rpm}$, and operating pressure: 3 bar.

Process operating optimization

For a fuller appraisal of the impact of operating conditions on productivity, we performed simulations to evaluate the dependency of the yield and energy consumption on agitation speed and operating pressure. Under the water feeding mode, the production yield increases gradually and then reached a plateau with increase of agitation speed and a fixed operating pressure (Figure 10a). This increase can be ascribed 
to the enhanced transportation of solute across the membrane, which is the result of less concentration polarization at higher agitation speed ${ }^{36}$. Higher permeate flux would increase the product retention due to a dilution effect ${ }^{38}$ that would lead to the existence of a plateau of production yield. At the same time, specific energy consumption increases monotonically owing to the greater power consumption at higher agitation speed (based on eq. (37)). Since the agitation speed is fixed, increasing operating pressure enhances the yield monotonically (Figure 10a) and thus decreases specific energy consumption (Figure 10b ), which is attributed to the monotonic increase of solute flux with operating pressure (Figure 8b ). Although the higher operating pressure together with lower agitation speed would lead to serious membrane fouling, it is beneficial in enhancing the production efficiency of the EMR system within an acceptable range of degree of fouling with the water feeding mode.

Additional simulations on the effects of agitation speed and operating pressure under the substrate feeding mode are summarized inFigure 11. The variation trends of yield and energy consumption with agitation speed obtained under the substrate feeding mode are consistent with those observed under the water feeding mode. However, when the agitation speed is fixed, the yield decreases gradually with increasing operating pressure under the substrate feeding mode, which is different from what is observed under the water feeding mode (Figure 11a). The reason is that the membrane surface suffers from more serious fouling which results in a lower flux under the substrate feeding mode as demonstrated in Figure 9a . In addition, the solute flux first increases then decreases with increase in operating pressure from 1 bar to 5 bar under the substrate feeding mode (Figure S2 ). This observation correlates well with the variation of the specific energy consumption as shown in Figure 11b. The specific energy consumption decreases first then increases to result in an optimal specific energy consumption at each given agitation speed (Figure 11b ). For instance, the optimal specific energy consumption of $13.2 \mathrm{kWh} / \mathrm{kg}$ is obtained at an operating pressure of 2 bar because the agitation is fixed at $1800 \mathrm{rpm}$. In conclusion, selection of a higher agitation speed and an optimal operating pressure can promote production of oligodextran and simultaneously decrease energy consumption under the substrate feeding mode.

From a practical perspective, the substrate feeding mode is a better alternative in large scale applications because of easy continuous operation and low energy consumption, but severe membrane fouling hinders its industrial implementation ${ }^{6}$. The extremely low permeate flux resulting from membrane fouling decreases the filtration efficiency and thus leads to increased operating costs. In addition, the substrate is easily overly hydrolyzed because the products cannot be removed in a timely manner due to low permeate flux. Consequently, development of membrane fouling control strategy in EMR systems deserves further attention for its potential to be fully realized.

Figure 10. Simulation investigation of the effect of agitation speed and operating pressure on (a) production yield and (b) specific energy consumption with membrane pore size of $10 \mathrm{~nm}$ and membrane porosity of 0.8 . Substrate concentration: $50 \mathrm{~g} / \mathrm{L}$, enzyme concentration: $0.05 \mathrm{~g} / \mathrm{L}$, operation duration: $240 \mathrm{~min}$, and feeding mode: water feeding.

Figure 11. Simulation investigation of the effect of agitation speed and operating pressure on (a) production yield and (b) specific energy consumption with membrane pore size of $10 \mathrm{~nm}$ and membrane porosity of 0.8 . Substrate concentration: $50 \mathrm{~g} / \mathrm{L}$, enzyme concentration: $0.05 \mathrm{~g} / \mathrm{L}$, operation duration: $240 \mathrm{~min}$, and feeding mode: substrate feeding.

\section{Conclusions}

In this study, a mathematical model is proposed to simulate the filtration performance of an EMR system for oligodextran production. The model was validated by a series of bench-scale experiments. Our modeling study evaluates the influence of selected membrane properties and operating conditions on EMR performance. The simulations demonstrate that uniform membrane pore size distribution and larger membrane porosity can significantly improve filtration efficiency and the quality of products;. Furthermore, although higher permeate flux may decrease energy consumption, it also reduces permeate concentration possibly due to a denser fouling layer, shorter retention time for hydrolysis, and more water convection transport (dilution 
effect). Different feeding modes resuls in different mechanisms of solute transport and thus affect the choice of operating pressure and agitation speed. Under the water feeding mode a more favorable performance can be obtained by applying a greater driving force together with a lower agitation speed to reduce fouling tendency. In contrast, the major challenge of the substrate feeding mode is more severe membrane fouling, therefore intense agitation together with medium operating pressure is beneficial for enhancing production efficiency. Our study theoretically highlights the technical feasibility as well as the practical constraints of an EMR system while providing important insights for its further development. Additional investigations can be performed on the pilot-scale EMR system operating in continuous mode. Other studies may be also required to explore EMR performance using various membrane module configurations (e.g. hollow fiber membrane modules, dynamic filtration modules with rotating or vibrating membranes etc.) to optimize system operation.

\section{Acknowledgments}

Dr. X. Li gratefully acknowledges the European Union's Horizon 2020 Research and Innovation Program for funding under Marie Sklodowska-Curie Grant Agreement No. 713683 (COFUNDfellowsDTU).

\section{List of Symbols}

Latin symbols

$A_{H}$ Hamaker constant (-)

$c$ a constant (-)

$C_{1}$ correction factor of tangential drag (-)

$C_{2}$ correction factor of normal drag (-)

$c_{d}$ dextran concentration $\left(\mathrm{g} \mathrm{L}^{-1}\right)$

$C_{f}$ feed concentration $\left(\mathrm{g} \mathrm{L}^{-1}\right)$

$C_{p}$ permeate concentration $\left(\mathrm{g} \mathrm{L}^{-1}\right)$

$C_{w}$ concentration of solute near the membrane surface $\left(\mathrm{g} \mathrm{L}^{-1}\right)$

$D$ equilibrium distance $(\mathrm{m})$

$D_{i}$ diameter of impeller $(\mathrm{m})$

$d_{p}$ particle diameter $(\mathrm{m})$

$D_{\text {[?] }}$ diffusion coefficient of the solute $\left(\mathrm{m}^{2} \mathrm{~s}^{-1}\right)$

$e$ electrical charge $(\mathrm{C})$

$E$ specific energy consumption $\left(\mathrm{kWh} \mathrm{kg}^{-1}\right)$

$e_{o}$ absolute permittivity $\left(\mathrm{C}^{2} \mathrm{~J}^{-1} \mathrm{~m}^{-1}\right)$

$e_{r}$ dielectric constant (-)

$F_{e}$ electrostatic force $(\mathrm{N})$

$F_{f}$ friction force $(\mathrm{N})$

$F_{g}$ net gravitational force $(\mathrm{N})$

$F_{l}$ inertial lift force $(\mathrm{N})$

$F_{n}$ net interparticle force $(\mathrm{N})$

$F_{p}$ normal drag force $(\mathrm{N})$ 
$F_{s}$ solid compressive force $(\mathrm{N})$

$F_{t}$ tangential drag force $(\mathrm{N})$

$F_{v}$ van der Waals force $(\mathrm{N})$

$h$ blade height $(\mathrm{m})$

$J$ permeate flux $\left(\mathrm{m}^{3} \mathrm{~m}^{-2} \mathrm{~s}^{-1}\right)$

$k$ rate constant $\left(\mathrm{Da}^{-1} \mathrm{~min}^{-1}\right)$

$k_{B}$ Boltzmann constant $\left(\mathrm{J} \mathrm{K}^{-1}\right)$

$K_{c}$ convective hindrance factor (-)

$K_{d}$ diffusive hindrance factor (-)

$k_{m}$ bulk mass transfer coefficient $\left(\mathrm{m} \mathrm{s}^{-1}\right)$

$k_{o}$ Kozeny constant (-)

$K_{p}$ membrane specific constant $\left(\mathrm{m}^{-1}\right)$

$L$ cake thickness $(\mathrm{m})$

$M_{o}$ initial molecular weight (Da)

$M_{f}$ mass of dextran substrate in the feed $(\mathrm{kg})$

$M_{\text {lim }}$ limiting molecular weight (Da)

$M_{p}$ dextran mass in the permeate $(\mathrm{kg})$

$M_{t}$ molecular weight at a certain reaction time (Da)

$M_{w}$ molecular weight (Da)

$n_{b}$ number of blades (-)

$n_{i}$ number of ions per unit volume (-)

$N_{s}$ solute flux $\left(\mathrm{g} \mathrm{m}^{-2} \mathrm{~s}^{-1}\right)$

$N_{T}$ dimensionless power number (-)

$P$ operating pressure $(\mathrm{Pa})$

$P_{a}$ power for generating the applied pressure (W)

$P e_{m}$ Peclet number (-)

$P_{s}$ power dissipated by a stirrer $(\mathrm{W})$

$Q$ permeate flow rate $\left(\mathrm{m}^{3} \mathrm{~s}^{-1}\right)$

$r$ a constant with a function of cake porosity (-)

$R$ radius of the stirred cell $(\mathrm{m})$

Re Reynolds number (-)

$R_{c}$ critical radius $(\mathrm{m})$

$R_{m}$ membrane intrinsic resistance $\left(\mathrm{m}^{-1}\right)$

$R_{p}$ pore radius of membrane $(\mathrm{m})$ 
$R_{s}$ solute radius (m)

$R_{t}$ overall filtration resistance $\left(\mathrm{m}^{-1}\right)$

$S$ membrane effective area $\left(\mathrm{m}^{2}\right)$

$S_{a}$ actual membrane sieving coefficient (-)

$S_{e}$ pore surface area $\left(\mathrm{m}^{2}\right)$

$S_{o}$ observed sieving coefficient (-)

$S_{p}$ specific surface area of particle $\left(\mathrm{m}^{2}\right)$

$S_{[?]}$ asymptotic sieving coefficient (-)

$t$ reaction time $(\min )$

$T$ filtration time (h)

$T_{e}$ absolute temperature (K)

$v_{l}$ inertial lift velocity of particles $\left(\mathrm{m} \mathrm{s}^{-1}\right)$

$V_{p}$ pore volume $\left(\mathrm{m}^{3}\right)$

$w_{c}$ cake mass $\left(\mathrm{kg} \mathrm{m}^{-2}\right)$

$Y$ yield of product (-)

$z_{i}$ valence of ions of type $i(-)$

Greek Letters

$a_{a}$ average specific filtration resistance of cake layer $\left(\mathrm{m} \mathrm{kg}^{-1}\right)$

$a_{\delta}$ average specific filtration resistances of dextran $\left(\mathrm{m} \mathrm{kg}^{-1}\right)$

$a_{\epsilon}$ average specific filtration resistances of enzyme $\left(\mathrm{m} \mathrm{kg}^{-1}\right)$

$\gamma$ shear rate $\left(\mathrm{s}^{-1}\right)$

$\delta$ Stern layer thickness of particle $(\mathrm{m})$

$\delta_{S}$ thickness of momentum boundary layer $(\mathrm{m})$

$\delta_{\mu}$ thickness of functional layer (m)

$\epsilon$ cake porosity (-)

$\epsilon_{\mu}$ membrane porosity (-)

$\epsilon_{o}$ porosity of the most compact cake layer (-)

$\zeta$ zeta potential of particle $(\mathrm{V})$

$\kappa$ reciprocal of double layer thickness $\left(\mathrm{m}^{-1}\right)$

$\lambda$ ratio of solute radius to pore radius (-)

$\lambda_{\pi}$ characteristic wavelength of particle $(\mathrm{m})$

$\mu$ feed viscosity ( $\mathrm{Pa} \mathrm{s}$ )

$\mu_{\mu a \xi}$ maximum friction coefficient (-)

$\nu$ kinematic viscosity $\left(\mathrm{m}^{2} \mathrm{~s}^{-1}\right)$ 


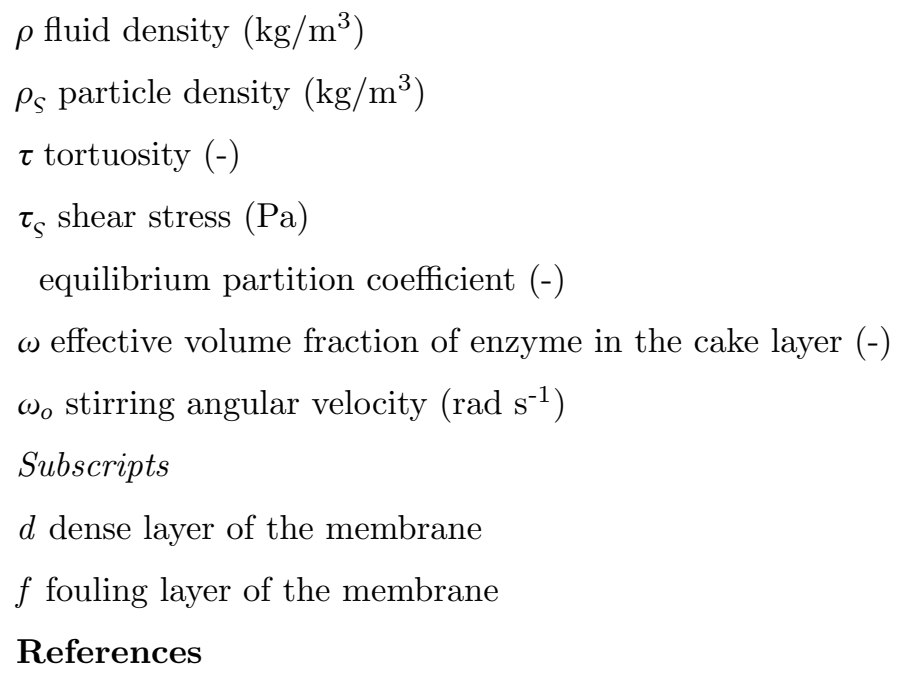

1. Charbonneau MR, O’Donnell D, Blanton LV, Totten SM, Davis JCC, Barratt MJ, Cheng J, Guruge J, Talcott M, Bain JR, Muehlbauer MJ, Ilkayeva O, Wu C, Struckmeyer T, Barile D, Mangani C, Jorgensen J, Fan YM, Maleta K, Dewey KG, Ashorn P, Newgard CB, Lebrilla C, Mills DA, Gordon JI. Sialylated milk oligosaccharides promote microbiota-dependent growth in models of infant undernutrition. Cell 2016;164:859-871.

2. Muanprasat C, Chatsudthipong V. Chitosan oligosaccharide: Biological activities and potential therapeutic applications. Pharmacol. Therapeut. 2017;170:80-97.

3. Li T, Liu L, Wei N, Yang JY, Chapla DG, Moremen KW, Boons GJ. An automated platform for the enzyme-mediated assembly of complex oligosaccharides. Nat. Chem. 2019;11:229-236.

4. Zhong C, Duić B, Bolivar JM, Nidetzky B. Three-enzyme phosphorylase cascade immobilized on solid support for biocatalytic synthesis of cello-oligosaccharides. Chem CatChem 2020;12:1350-1358.

5. Pinelo M, Jonsson G, Meyer AS. Membrane technology for purification of enzymatically produced oligosaccharides: molecular and operational features affecting performance. Sep. Purif. Technol.2009;70:1-11.

6. Alam Z, Luo J, Li X, Pinelo M. Enzyme membrane reactors for production of oligosaccharides: A review on the interdependence between enzyme reaction and membrane separation. Sep. Purif. Technol.2020;243:116840.

7. Torras C, Nabarlatz D, Vallot G, Montané D, Garcia-Valls R. Composite polymeric membranes for process intensification: enzymatic hydrolysis of oligodextrans. Chem. Eng. J. 2008;144:259-266.

8. Pu Y, Zou Q, Liu L, Han Z, Wang X, Wang Q, Chen S. Clinical dextran purified by fractional ultrafiltration coupled with water washing. Carbohydr. Polym. 2012;87:1257-1260.

9. Luo J, Meyer AS, Jonsson G, Pinelo M. Enzyme immobilization by fouling in ultrafiltration membranes: impact of membrane configuration and type on flux behavior and biocatalytic conversion efficacy.Biochem. Eng. J. 2014;83:79-89.

10. Su Z, Luo J, Pinelo M, Wan Y. Directing filtration to narrow molecular weight distribution of oligodextran in an enzymatic membrane reactor.J. Membr. Sci. 2018;555:268-279.

11. Alam MNHZ, Pinelo M, Samanta K, Jonsson G, Meyer AS, Gernaey KV. A continuous membrane microbioreactor system for development of integrated pectin odification and separation processes. Chem. Eng. J. 2011;167(2-3):418-426.

12. du Preeza R, Clarke KG, Callanan LH, Burton SG. Modelling of immobilised enzyme biocatalytic membrane reactor performance. J. of Mol. Catal. B: Enzym. 2015;119:48-53.

13. Curcio S, Calabrò V, Iorio G. A theoretical and experimental analysis of a membrane bioreactor performance in recycle configuration.J. Membr. Sci. 2006;273:129-142.

14. Fischer H, Polikarpov I, Craievich AF. Average protein density is a molecular-weight-dependent function. Protein Sci.2004;13:2825-2828. 
15. Hou DZ, Huang SX, Chen S. Biosynthesis of oligodextrans through synergistic catalysis of dextransucrase and dextranase in a recycle membrane bioreactor. Sugar Tech. 2018; 20(5):566-573.

16. ŃSka MP, Szczodrak J, Rogalski J, Fiedurek J. Hydrolysis of dextran byPenicillium notatum dextranase and identification of final digestion products. Mycol. Res. 1997;101:69-72.

17. Hwang KJ, Yang SS. The role of polysaccharide on the filtration of microbial cells. Sep. Purif. Technol. 2011;46:786-793.

18. Broeckmann A, Busch J, Wintgens T, Marquardt W. Modeling of pore blocking and cake layer formation in membrane filtration for wastewater treatment. Desalination 2006;189:97-109.

19. Lu WM, Hwang KJ. Cake formation in 2-D cross-flow filtration. AIChE J. 1995;41:1443-1455.

20. Hwang KJ, Liu HC, Lu WM. Local properties of cake in cross-flow microfiltration of submicron particles. J. Membr. Sci.1998;138:181-192.

21. Becht NO, Malik DJ, Tarleton ES. Evaluation and comparison of protein ultrafiltration test results: Dead-end stirred cell compared with a cross-flow system. Sep. Purif. Technol. 2008;62:228-239.

22. Vasseur P, Cox RG. The lateral migration of spherical particle in two dimensional shear flow. J. Fluid Mech. 1976;78:385-413.

23. Opong WS, Zydney AL. Diffusive and convective protein transport through asymmetric membranes. AIChE J. 1991;37:1497-1510.

24. Granath KA. Solution properties of branched dextrans. J. Colloid Sci. 1958;13:308-328.

25. Zeman LJ, Zydney AL. Microfiltration and ultrafiltration: Principles and applications. New York: Marcel Dekker, Inc., 1996.

26. Zydney AL, Xenopoulos A. Improving dextran tests for ultrafiltration membranes: Effect of device format. J. Membr. Sci.2007;291:180-190.

27. Boyd RF, Zydney AL. Sieving characteristics of multilayer ultrafiltration membranes. J. Membr. Sci. 1997;131:155-165.

28. Mochizuki S, Zydney AL. Dextran transport through asymmetric ultrafiltration membranes: Comparison with hydrodynamic models.J. Membr. Sci. 1992;66:21-41.

29. Shamsuddin N, Das DB, Starov VM. Filtration of natural organic matter using ultrafiltration membranes for drinking water purposes: Circular cross-flow compared with stirred dead end flow. Chem. Eng. J.2015;276:331-339.

30. Foucault S, Ascanio G, Tanguy PA. Power characteristics in coaxial mixing: newtonian and nonnewtonian fluids. Ind. Eng. Chem. Res. 2005;44:5036-5043.

31. Zheng QZ, Wang P, Yang YN, Cui DJ. The relationship between porosity and kinetics parameter of membrane formation in PSF ultrafiltration membrane. J. Membr. Sci. 2006;286:7-11.

32. Bakeri G, Ismail AF, DashtArzhandi MR, Matsuura T. Porous PES and PEI hollow fiber membranes in a gas-liquid contacting process-A comparative study. J. Membr. Sci. 2015;475:57-64.

33. Costa AR, de Pinho MN, Elimelech M. Mechanisms of colloidal natural organic matter fouling in ultrafiltration. J. Membr. Sci.2006;281:716-725.

34. Bashari M, Tounkara F, Abdelhai MH, Lagnika C, Xu X, Jin Z. Impact of dextranase on sugar manufacturing and its kinetic on the molecular weights of remaining dextran. Sugar Tech. 2013;15(1):84-93.

35. Wickramasinghe SR, Bower SE, Chen Z, Mukherjee A, Husson SM. Relating the pore size distribution of ultrafiltration membranes to dextran rejection. J. Membr. Sci. 2009;340:1-8.

36. Meng BY, Li XY. In situ visualization of concentration polarization during membrane ultrafiltration using microscopic laser-induced fluorescence. Environ. Sci. Technol. 2019;53:2660-2669.

37. Mehta A, Zydney AL. Permeability and selectivity analysis for ultrafiltration membranes. J. Membr. Sci. 2005;249:245-249.

38. Luo J, Morthensen ST, Meyer AS, Pinelo M. Filtration behavior of casein glycomacropeptide (CGMP) in an enzymatic membrane reactor: fouling control by membrane selection and threshold flux operation.J. Membr. Sci. 2014;469:127-139.

39. Baldassarre S, Babbar N, Roy SV, Dejonghe W, Maesen M, Sforza S, Elst K. Continuous production of pectic oligosaccharides from onion skins with an enzyme membrane reactor. Food Chem. 2018;267:101110. 


\section{Hosted file}

image2.emf available at https://authorea.com/users/331266/articles/457956-mathematicalmodelling-of-reaction-separation-in-an-enzymatic-membrane-reactor-during-oligodextranproduction

Figure 1. Schematic diagram of an enzymatic membrane reactor for oligodextran production.

\section{Hosted file}

image3.emf available at https://authorea.com/users/331266/articles/457956-mathematicalmodelling-of-reaction-separation-in-an-enzymatic-membrane-reactor-during-oligodextranproduction

Figure 2. Schematic diagram of the methodology used in this work.

Table 1. Parameters used for model simulation

\begin{tabular}{ll}
\hline Parameters & Values \\
\hline Operating pressure $(P)$ Agitation speed & $1-5 \mathrm{bar} 100-2000 \mathrm{rpm}$ \\
Dextran substrate concentration $C_{f}$ & $50 \mathrm{~g} / \mathrm{L}$ \\
volume of dead-end stirred cell & $50 \mathrm{ml}$ \\
Mw of dextran substrate & $40 \mathrm{kDa}$ \\
Enzyme of dextranase concentration & $0.5 \mathrm{~g} / \mathrm{L}$ \\
Mw of dextranase & $67 \mathrm{kDa}$ \\
Membrane area $(S)$ & $0.0014 \mathrm{~m}^{2}$ \\
Average pore size of membrane $\left(R_{p}\right)^{10}$ & $10 \mathrm{~nm}$ \\
Membrane porosity $\left(\epsilon_{\mu}\right)^{31}$ & 0.8 \\
Membrane tortuosity $(\tau)^{32}$ & 1.6 \\
Viscosity of feed solution $(\mu)^{33}$ & $3.5 \times 10^{-3} \mathrm{~Pa} \cdot \mathrm{s}$ \\
Density of feed solution $(\rho)^{33}$ & $1050 \mathrm{~kg} / \mathrm{m}^{3}$ \\
\hline
\end{tabular}

\section{Hosted file}

image4.emf available at https://authorea.com/users/331266/articles/457956-mathematicalmodelling-of-reaction-separation-in-an-enzymatic-membrane-reactor-during-oligodextranproduction

\section{Hosted file}

image5.emf available at https://authorea.com/users/331266/articles/457956-mathematicalmodelling-of-reaction-separation-in-an-enzymatic-membrane-reactor-during-oligodextranproduction

(a) (b)

Figure 3 . Effect of dextran concentration on (a) the variation of average $\mathrm{Mw}$ with reaction time and (b) the values of rate constant $(k)$ in a batch system with free enzyme. The simulated results are plotted as curves, while the experimental results are presented as discrete symbols.

\section{Hosted file}

image6.emf available at https://authorea.com/users/331266/articles/457956-mathematicalmodelling-of-reaction-separation-in-an-enzymatic-membrane-reactor-during-oligodextranproduction

\section{Hosted file}


image7.emf available at https://authorea.com/users/331266/articles/457956-mathematicalmodelling-of-reaction-separation-in-an-enzymatic-membrane-reactor-during-oligodextranproduction

(a) (b)

Figure 4. Experimental (solid line) and simulated (discrete symbols) profiles of (a) permeate flux and (b) permeate concentration versus operation time with membrane pore size of $10 \mathrm{~nm}$ and membrane porosity of 0.8. Substrate concentration: $50 \mathrm{~g} / \mathrm{L}$, enzyme concentration: $0.05 \mathrm{~g} / \mathrm{L}$, agitation speed: $160 \mathrm{rpm}$, and feeding mode: water feeding.

\section{Hosted file}

image8.emf available at https://authorea.com/users/331266/articles/457956-mathematicalmodelling-of-reaction-separation-in-an-enzymatic-membrane-reactor-during-oligodextranproduction

\section{Hosted file}

image9.emf available at https://authorea.com/users/331266/articles/457956-mathematicalmodelling-of-reaction-separation-in-an-enzymatic-membrane-reactor-during-oligodextranproduction

(a) (b)

Figure 5. Simulation investigation of the effect of the pore size of membrane on (a) permeate flux and (b) permeate concentration with membrane porosity of 0.8 . Substrate concentration: $50 \mathrm{~g} / \mathrm{L}$, enzyme concentration: $0.05 \mathrm{~g} / \mathrm{L}$, operating pressure: $3 \mathrm{bar}$, agitation speed: $1000 \mathrm{rpm}$, and feeding mode: water feeding.

\section{Hosted file}

image10.emf available at https://authorea.com/users/331266/articles/457956-mathematicalmodelling-of-reaction-separation-in-an-enzymatic-membrane-reactor-during-oligodextranproduction

\section{Hosted file}

image11.emf available at https://authorea.com/users/331266/articles/457956-mathematicalmodelling-of-reaction-separation-in-an-enzymatic-membrane-reactor-during-oligodextranproduction

(a) (b)

Figure 6. Simulation investigation of the effect of membrane porosity on (a) permeate flux and (b) permeate concentration with membrane pore size of $10 \mathrm{~nm}$. Substrate concentration: $50 \mathrm{~g} / \mathrm{L}$, enzyme concentration: $0.05 \mathrm{~g} / \mathrm{L}$, operating pressure: 3 bar, agitation speed: $1000 \mathrm{rpm}$, and feeding mode: water feeding.

\section{Hosted file}

image12.emf available at https://authorea.com/users/331266/articles/457956-mathematicalmodelling-of-reaction-separation-in-an-enzymatic-membrane-reactor-during-oligodextranproduction

\section{Hosted file}

image13.emf available at https://authorea.com/users/331266/articles/457956-mathematicalmodelling-of-reaction-separation-in-an-enzymatic-membrane-reactor-during-oligodextranproduction

(a) (b) 


\section{Hosted file}

image14.emf available at https://authorea.com/users/331266/articles/457956-mathematicalmodelling-of-reaction-separation-in-an-enzymatic-membrane-reactor-during-oligodextranproduction

(c)

Figure 7. Simulation investigation of the effect of agitation speed on (a) permeate flux, (b) solute flux, and (c) permeate concentration with membrane pore size of $10 \mathrm{~nm}$ and membrane porosity of 0.8 . Substrate concentration: $50 \mathrm{~g} / \mathrm{L}$, enzyme concentration: $0.05 \mathrm{~g} / \mathrm{L}$, operating pressure: 1 bar, and feeding mode: water feeding.

\section{Hosted file}

image15.emf available at https://authorea.com/users/331266/articles/457956-mathematicalmodelling-of-reaction-separation-in-an-enzymatic-membrane-reactor-during-oligodextranproduction

\section{Hosted file}

image16.emf available at https://authorea.com/users/331266/articles/457956-mathematicalmodelling-of-reaction-separation-in-an-enzymatic-membrane-reactor-during-oligodextranproduction

\section{(a) (b)}

\section{Hosted file}

image17.emf available at https://authorea.com/users/331266/articles/457956-mathematicalmodelling-of-reaction-separation-in-an-enzymatic-membrane-reactor-during-oligodextranproduction

\section{(c)}

Figure 8. Simulation investigation of the effect of operating pressure on (a) permeate flux, (b) solute flux, and (c) permeate concentration with membrane pore size of $10 \mathrm{~nm}$ and membrane porosity of 0.8 . Substrate concentration: $50 \mathrm{~g} / \mathrm{L}$, enzyme concentration: $0.05 \mathrm{~g} / \mathrm{L}$, agitation speed: $1000 \mathrm{rpm}$, and feeding mode: water feeding.

\section{Hosted file}

image18.emf available at https://authorea.com/users/331266/articles/457956-mathematicalmodelling-of-reaction-separation-in-an-enzymatic-membrane-reactor-during-oligodextranproduction

\section{Hosted file}

image19.emf available at https://authorea.com/users/331266/articles/457956-mathematicalmodelling-of-reaction-separation-in-an-enzymatic-membrane-reactor-during-oligodextranproduction

(a) (b)

\section{Hosted file}

image20.emf available at https://authorea.com/users/331266/articles/457956-mathematicalmodelling-of-reaction-separation-in-an-enzymatic-membrane-reactor-during-oligodextranproduction

\section{Hosted file}


image21.emf available at https://authorea.com/users/331266/articles/457956-mathematicalmodelling-of-reaction-separation-in-an-enzymatic-membrane-reactor-during-oligodextranproduction

(c) $(\mathrm{d})$

Figure 9. Simulation investigation of the effect of feeding mode on (a) permeate flux, (b) solute flux, (c) permeate concentration, and (d) yield and specific energy consumption with membrane pore size of $10 \mathrm{~nm}$ and membrane porosity of 0.8 . Substrate concentration: $50 \mathrm{~g} / \mathrm{L}$, enzyme concentration: $0.05 \mathrm{~g} / \mathrm{L}$, agitation speed: $1000 \mathrm{rpm}$, and operating pressure: $3 \mathrm{bar}$.

\section{Hosted file}

image22.emf available at https://authorea.com/users/331266/articles/457956-mathematicalmodelling-of-reaction-separation-in-an-enzymatic-membrane-reactor-during-oligodextranproduction

\section{Hosted file}

image23.emf available at https://authorea.com/users/331266/articles/457956-mathematicalmodelling-of-reaction-separation-in-an-enzymatic-membrane-reactor-during-oligodextranproduction

(a) (b)

Figure 10. Simulation investigation of the effect of agitation speed and operating pressure on (a) production yield and (b) specific energy consumption with membrane pore size of $10 \mathrm{~nm}$ and membrane porosity of 0.8 . Substrate concentration: $50 \mathrm{~g} / \mathrm{L}$, enzyme concentration: $0.05 \mathrm{~g} / \mathrm{L}$, operation duration: $240 \mathrm{~min}$, and feeding mode: water feeding.

\section{Hosted file}

image24.emf available at https://authorea.com/users/331266/articles/457956-mathematicalmodelling-of-reaction-separation-in-an-enzymatic-membrane-reactor-during-oligodextranproduction

\section{Hosted file}

image25.emf available at https://authorea.com/users/331266/articles/457956-mathematicalmodelling-of-reaction-separation-in-an-enzymatic-membrane-reactor-during-oligodextranproduction

\section{(a) (b)}

Figure 11. Simulation investigation of the effect of agitation speed and operating pressure on (a) production yield and (b) specific energy consumption with membrane pore size of $10 \mathrm{~nm}$ and membrane porosity of 0.8 . Substrate concentration: $50 \mathrm{~g} / \mathrm{L}$, enzyme concentration: $0.05 \mathrm{~g} / \mathrm{L}$, operation duration: $240 \mathrm{~min}$, and feeding mode: substrate feeding. 